\title{
Brug af iframe-tag i html-filer til OJS under tidsskrift.dk
}

\section{Med en indlejret pdf-fil}

Normalt ville det uden for OJS være tilstrækkeligt at indsætte følgende kode i sit html-dokument: $<$ iframe src="filename.pdf" $><$ /iframe>

Men da OJS ikke indlæser det som et inline-tag, bliver man nødt til at tilrette html-koden på følgende vis: <iframe data-inline="1" src="filename.pdf" ></iframe>

Sammen med denne tilretning indsættes følgende tag i header-sektionen:

<script src="/plugins/themes/RoyalDanishLibrary/js/iframe.js" type="text/javascript" $></$ script $>$ i Hvis denne tilretning ikke foretages, vil en indlejret pdf-fil åbne op i Adope Reader eller lignende program og altså ikke i den indlejrede ramme i html-dokumentet.

Dette skulle løse problemet med indlejrede pdf-filer i et html-dokument, forudsat at pdf-filen er blevet uploadet via linket 'Upload fil' under 'Redigér et layoutsatsskib'

Redigér metadata Identifikator

Etiket *

HTML

Bruges til ot identificere elementets filformot (f.eks. HTML.

PDF Osv.) *

Dansk

Sprog*

Denne publiceringsversion vil være tilgæengelig på et separat website.

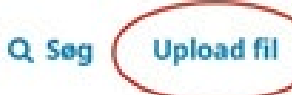




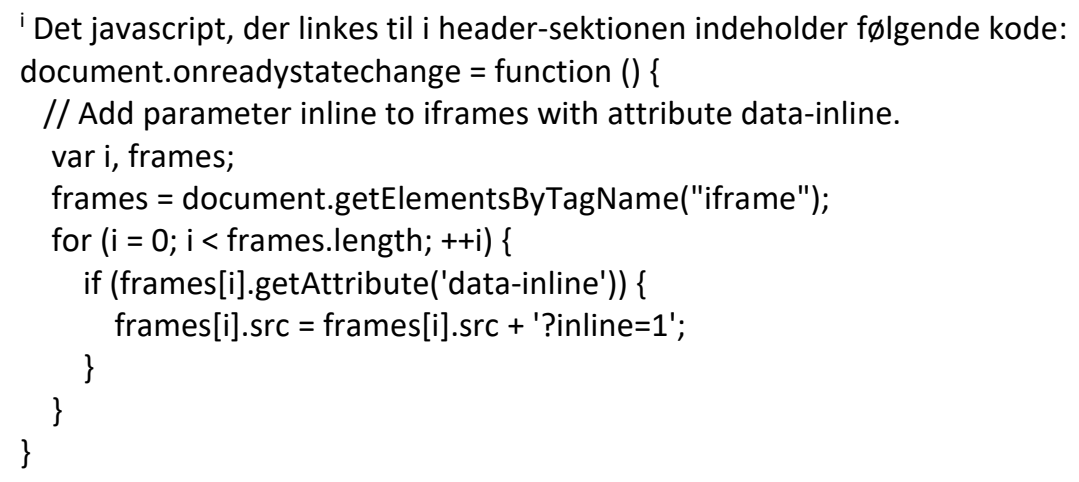

